\title{
CXCL1 Gene
}

National Cancer Institute

\section{Source}

National Cancer Institute. CXCL1 Gene. NCI Thesaurus. Code C18460.

This gene is involved in immune processes and has been implicated in cancer metastasis. 